NBER WORKING PAPER SERIES

FOOD PRICE SPIKES, PRICE INSULATION AND POVERTY

\author{
Kym Anderson \\ Maros Ivanic \\ Will Martin \\ Working Paper 19530 \\ http://www.nber.org/papers/w19530
NATIONAL BUREAU OF ECONOMIC RESEARCH
1050 Massachusetts Avenue
Cambridge, MA 02138
October 2013

We wish to thank Jean-Paul Chavas, David Hummels and Brian Wright for the opportunity to participate in this study and Marc Bellemare for valuable comments on the initial draft of the paper. Particular thanks are due to Signe Nelgen for assistance with the price distortions database. The views expressed herein are those of the authors and do not necessarily reflect the views of the National Bureau of Economic Research. This work benefitted from support by the Multi-donor Trust Fund for Trade at the World Bank.

NBER working papers are circulated for discussion and comment purposes. They have not been peerreviewed or been subject to the review by the NBER Board of Directors that accompanies official NBER publications.

(C) 2013 by Kym Anderson, Maros Ivanic, and Will Martin. All rights reserved. Short sections of text, not to exceed two paragraphs, may be quoted without explicit permission provided that full credit, including $(\subset)$ notice, is given to the source. 
Food Price Spikes, Price Insulation and Poverty

Kym Anderson, Maros Ivanic, and Will Martin

NBER Working Paper No. 19530

October 2013

JEL No. F13,Q02,Q17,Q18

\begin{abstract}
$\underline{\text { ABSTRACT }}$
This paper first considers the impact on world food prices of the changes in restrictions on trade in staple foods during the 2008 world food price crisis. Those changes-reductions in import protection or increases in export restraints - were meant to partially insulate domestic markets from the spike in international prices. The authors find that this insulation added substantially to the spike in international prices for rice, wheat, maize, and oilseeds. As a result, although domestic prices rose less than they would have without insulation in some developing countries, in many other countries they rose more than they would have in the absence of such insulation. The paper's second purpose it to estimate the combined impact of such insulating behavior on poverty in various developing countries and globally. The analysis finds that the actual poverty-reducing impact of insulation is much less than its apparent impact, and that its net effect was to increase global poverty in 2008 by 8 million people, although this increase was not significantly different from zero. The paper examines the relative efficiency and equity of trade restrictions and domestic policies, such as conditional cash transfers, than are designed to provide social protection for the poor when international food prices spike. It also examines the potential consequences of multilateral agreements to limit changes in restrictions on trade during such times.
\end{abstract}

Kym Anderson

University of Adelaide

School of Economics

Adelaide SA 5005

Australia

kym.anderson@adelaide.edu.au

Maros Ivanic

Development Research Group

MSN MC3-303

World Bank

1818 H St NW

Washington DC 20433

mivanic@worldbank.org
Will Martin

Development Research Group

MSN MC3-305

World Bank

1818 H St NW

Washington DC 20433

wmartin1@worldbank.org 


\section{Food Price Spikes, Price Insulation, and Poverty}

Many countries have responded to spikes in international food prices, such as those of mid 2008, early 2011 and mid 2012, by adjusting their agricultural trade barriers in an attempt to partially insulate their domestic markets from the price rises. Even when it may appear to each individual country that it has been successful, in the sense that its domestic price rose less than the international price for its food staples, this success is frequently more illusionary than real. The reason is that these policy responses - reductions in import protection or increases in export restraints - exacerbate the initial increase in the international price. Indeed, if both exporting and importing country groups happened to insulate to the same extent, domestic prices in both country groups would rise just as much as if no country had insulated (Martin and Anderson, 2012). In reality, however, countries intervened to different extents, so that the impact of price insulation depends on both the actions taken by the country itself and the collective impact of interventions by all other countries

The net effects on national and global poverty of such interventions could be favorable or unfavorable. On the one hand, if countries where the poor are most adversely affected by higher food prices insulate more than countries where the poor are less vulnerable to or benefit from food price spikes, it is possible that such insulation reduces the number of people driven into poverty. A related possibility is that, if countries where producers and consumers are better able to deal domestically with such shocks transmit a larger portion of the increase in international food prices to their domestic markets, the adverse global poverty impact of the original shock will be less (Timmer 2010).

On the other hand, a more pessimistic possibility is that many of the countries that insulate against shocks to international food prices are countries for which the impacts on 
domestic poverty of higher food prices are minor or even pro-poor in the case where most of the poor are net sellers of food staples. High-income countries, for example, are well-placed to absorb price shocks because of the small shares of farm produce in the expenditures of their consumers, their producers' access to risk management tools such as futures and options markets, and their relatively well-developed social safety nets. Even so, some high-income countries continue to use insulating policy instruments such as variable import levies, or even just specific tariffs whose ad valorem equivalent varies inversely with the border price. Another example of this possibility is where large, poor, food-importing countries - for which insulation is more expensive because it turns their terms of trade against them-insulate less than would a small but otherwise similar country, and hence may not avoid adverse poverty outcomes because of inadequate domestic social safety nets.

It is clear from these examples that, other things equal, alterations in trade restrictions could increase or reduce the national and global poverty impacts of higher international prices. Only by looking at data on the changes in agricultural distortions during periods of rapid increases in international food prices, and estimating the impacts of consequent domestic price changes on poverty in different countries is it possible to ascertain the net effects on national and global poverty.

This paper begins by looking at data on the consumption patterns and income sources of low-income households in a sample of thirty developing countries, where three-quarters of the world's poor live, in order to assess which commodities are likely to be important in affecting poverty through changes in their commodity prices. We then turn to data on agricultural price distortions, and in particular on relative movements in domestic and international prices, to 
assess the extent to which countries insulated their domestic market from the changes in international food prices during 2006-08.

With these data, we use a simple model to compare the actual changes in domestic prices with those that would have occurred in the absence of price-insulating policies. These price scenarios are then used to assess the impacts of food price changes on poverty both with — and in the absence of - price-insulating policy behavior. They allow us to make a much broader assessment of the impacts of price-insulating behavior on national and global poverty than has previously been available. The final section examines alternative policy measures at unilateral, regional and multilateral levels which — together with complementary domestic measuresmight more efficiently reduce the impact of future price spikes on poverty. The most costeffective policy instrument for dealing with the poverty impacts of price rises is likely to be a domestic one — such as a well-targeted social safety net — that deals directly with the problem of poverty vulnerability.

\section{What price changes are important for the poor?}

The direct short-run impact of food price changes on the well-being of a particular household depends on the proportional change in the real price of a particular food times the household's net purchases of that food (Deaton 1989). Since food typically makes up a large share of the spending of poor people, we would generally expect food price changes to have a large impact on the living costs of the poor. However, the vast majority of poor people are rural (threequarters, according to Ravallion et al, 2007), and most poor rural people earn their living from agriculture. Hence food expenditure shares alone are insufficient for determining the impact of 
food price changes on poverty: account also needs to be taken of the shares of household income obtained from the sale of food to obtain the net expenditures on food by the household.

The first two columns of Table 1 report the weighted-average shares of particular types of food in aggregate food expenditures and in total expenditures by the poor for the thirty developing countries for which we have detailed data on household expenditures and income sources. ${ }^{1}$ Columns three through nine of Table 1 net out household production, and so are the most relevant for present purposes. Six countries' shares are shown as examples, together with the weighted average for all thirty countries. The bottom row reveals that, for our sample of 30 countries, food accounts for 61 percent of the gross expenditures of their poor. While we would like to consider all food expenditures, only a few of these products are homogenous enough to have reasonably representative international prices so we focus on four-rice, wheat, oilseeds and maize - that account for 41 percent of those gross expenditures.

Table 1 also shows that the poor are, on average, net buyers of food in most poor countries. In only one of the countries shown (Vietnam) are the poor, as a group, net sellers of the listed foods in aggregate, and there are only a few other cases where the poor are net sellers of particular foods. Over the full sample of thirty countries, column 3 shows that the poor are net buyers for all of the food items listed except maize. That column also reveals that rice, wheat, oilseeds and maize account for 39 percent of the net food expenditures of the poor in our sample.

\footnotetext{
${ }^{1}$ The household survey years are Albania 2005, Armenia 2004, Bangladesh 2005, Belize 2009, China 2002, Côte d'Ivoire 2002, Ecuador 2006, Guatemala 2006, Indonesia 2007, India 2004, Cambodia 2003, Sri Lanka 2007, Moldova 2009, Mongolia 2002, Malawi 2004, Nepal 2002, Nigeria 2003, Nicaragua 2005, Niger 2007, Pakistan 2005, Rwanda 2005, Tajikistan 2007, Timor Leste 2001, Tanzania 2008, Uganda 2009, Vietnam 2010 , Yemen 2006 and Zambia 2010.
} 


\section{Extent of domestic price changes, 2006-08}

The changes between 2006 and 2008 in domestic prices of each of these four key food items in each of the thirty sample countries for which we have information on both income sources and expenditure patterns are shown in Table 2, together with changes in nominal non-food prices as measured by the non-food component of the consumer price index for each country. ${ }^{2}$ Clearly domestic prices of these key foods generally rose considerably relative to non-food prices during this period.

\section{Impacts of changes in price distortions on international prices}

To obtain an indication of the impact of the observed changes in trade restrictions on domestic prices, we need first to estimate their impact on international prices. That involves taking account of the changes in price distortions in countries that collectively account for a large share of world consumption. Following Martin and Anderson (2012), to assess the implications of price insulation on a homogenous product's international price, $p^{*}$, we begin with the global market equilibrium condition:

$$
\text { Equation } 1 \quad \sum_{i}\left(S_{i}\left(p_{i}\right)+v_{i}\right)-\sum_{i}\left(D_{i}\left(p_{i}\right)+v_{i}\right)=0
$$

where $S_{i}$ is the supply in region $i ; p_{i}$ is the region's producer price; $v_{i}$ is a random production shift variable for that region; $D_{i}$ is demand in region $i$ (assumed to be not subject to shocks from year to year); and $p_{i}$ is the consumer price in region $i$. We assume that $p_{i}=\left(1+t_{p}\right) p^{*}$ where $t_{p}$ is the rate of distortion between the producer price and international price, and that $p_{i}=$

\footnotetext{
${ }^{2}$ Computed by using sample-average weights for food expenditures to remove the observed influence of the food CPI from the overall CPI numbers obtained from FAO.
} 
$\left(1+t_{c}\right) p^{*}$ where $t_{c}$ is the rate of distortion between the consumer price and international price. With a focus on border measures, we can use a single variable for the power of the trade tax equivalent, $T=1+t$ where $t=t_{p}=t_{c}$.

Totally differentiating Equation 1, rearranging it, and expressing the results in percentage change form yields the following expression for the impact of a set of changes in trade distortions on the international price:

Equation $2 \quad \hat{p}^{*}=\frac{\sum_{i} H_{i} \hat{v}_{i}+\sum_{i}\left(H_{i} \gamma_{i}-G_{i} \eta_{i}\right) \hat{T}_{i}}{\sum_{i}\left(G_{i} \eta_{i}-H_{i} \gamma_{i}\right)}$

where $\hat{p}^{*}$ is the proportional change in the international price; $\hat{v}_{i}$ is an exogenous stochastic shock to output such as might result from better or worse weather than average; $\eta_{i}$ is the elasticity of demand; $\gamma_{i}$ is the elasticity of supply; $G_{i}$ is the share at international prices of country $i$ in global demand; and $H_{i}$ is the share of country $i$ in global production. That is, the impact on the international price of a change in trade distortions in country $i$ depends on the importance of that country in global supply and demand, as well as the responsiveness of its production and consumption to price changes in the country, as represented by $\gamma_{i}$ and $\eta_{i}$. Note that if all countries alter their distortions by a uniform amount $\left(\widehat{T}_{i}\right.$ the same for all $\left.i\right)$, the elasticities of supply and demand are irrelevant to the impact on international prices, which will change by an exactly-offsetting amount and so mean domestic prices rise as if no countries insulated.

If we assume that output cannot respond in the short run and that inventory levels were low enough in this high-price period that stock adjustments have no effect, then $\gamma_{i}=0$. If we further assume that the national elasticities of final demand $\left(\eta_{i}\right)$ are the same across countries, then Equation 2 suggests we can estimate the contribution to international price changes 
resulting from changes in national trade restrictions as simply the negative of the consumptionweighted global average of the $\widehat{T}_{i}$ 's. To avoid dealing with interaction terms, we convert all proportional changes into log-change form and decompose the change in the domestic price in country $\mathrm{i}$ into the change in the world price and in the country's own protection:

$$
\text { Equation } 3 \quad \Delta \ln p_{i}=\Delta \ln p_{w}+\Delta \ln T_{i}
$$

We are particularly interested in what the percentage change in the domestic price would be in each country if all countries had refrained from insulating. This is obtained by estimating the change in the international price that would result from all countries reversing their insulating actions, plus the change from reversing country $i$ 's own interventions. The proportional change in $p$ from its initial level can be recovered by recalling that, if we set the initial price level at unity,

$$
\text { Equation } 4 \quad \Delta \ln p=\ln (1+\hat{\mathrm{p}})
$$

If, for instance, all countries reduce the power of the protection rate applied in their market by 10 percent, the world price will rise by 10 percent. This means that a country that changes its national protection by less than the weighted average global change in trade taxation will experience a change in domestic prices that is larger than it would have experienced absent insulation by all countries.

Estimates of the impacts of price-insulating behavior on international prices are reported in the first column of Table $3 .^{3}$ These are derived from annual protection changes estimated

\footnotetext{
${ }^{3}$ To test the sensitivity of those results, column 2 of Table 3 reports the results if the supply elasticity is as high as unity instead of zero in each country and the common demand elasticity is set at -0.2. Clearly, using these different demand and supply elasticity assumptions makes little difference to the estimates (assuming still that those elasticities are uniform across countries). This result is not unexpected given that net trade is a small share of
} 
using domestic and border prices for those key food items in 103 countries that together account for more than 90 percent of the world market for each of rice, wheat, maize and edible oils. Most of those are obtained from the 82-country sample in the Distortions to Agricultural Incentives (DAI) database that was recently updated by Anderson and Nelgen (2013). ${ }^{4}$ Because the DAI database does not include data for some of the smaller developing countries for which we have household data, we supplement the DAI data with estimates from other sources, particularly the FAO's domestic price and trade series. Details are provided in the Appendix. The results in column 1 of Table 3 suggest that the aggregate effect of all countries' price-insulating behavior during 2006-08 was to raise the price in the international marketplace by 52 percent for rice, by 18 percent for both wheat and maize, and by 31 percent for edible oils. ${ }^{5}$

The extent of the contribution by each country to the changes in international rice, wheat, maize and oilseed prices can be seen by the size of each country's shaded rectangle in Figure 1. In this diagram, the countries whose protection (measured by the proportional change in $T$ ) fell by more than the increase in the international price - also shown in Figure 1 as the 'world price impact' line - were effective in sheltering themselves from at least part of the increase in that price. Those countries where protection fell by less than the increase in the international price experienced a domestic price rise that was greater than would have occurred in the absence of

production and consumption of these food items in most countries, making each country's share of world output very similar to its consumption share.

${ }^{4}$ For this study, a particularly important change from the version of the DAI used in earlier versions of this study was a move from using unit values to international indicator prices when updating changes in international prices. Of greatest importance for this study was the case of rice in India where the estimates of export prices in Pursell, Gulati and Gupta (2009) were originally updated using export unit values and are now updated as an index to parallel the proportional increase in the Thai 5\% broken rice price. For 2006-2008, the unit value of India's exports was strongly affected by a large increase in the share of much-more-expensive basmati rice exports.

${ }^{5}$ These are slightly higher from the comparable estimates for the three cereals in Martin and Anderson (2012), because a larger sample of countries is used here. 
insulation by all countries. Countries whose protection rate did not change experienced the full proportional increase in the international price - an increase that results from both the original shock and the additional effect of all countries' price insulation.

For rice, it appears that China, Indonesia and Bangladesh reduced their protection enough to have a smaller domestic price increase than they would have experienced without insulation by any country. Other countries, such as India and the Philippines, insulated themselves to some degree from the increase in the international rice price, but not by enough to offset the priceincreasing effect of all countries' collective action. That is, for these and other countries their domestic rice price increased more than it would have done in the absence of their own and all other countries' insulation.

For wheat, the countries that insulated sufficiently that their domestic price rose by less than it would have in the absence of insulation by all countries include China, India, Turkey, Pakistan and Japan. While most other countries insulated to some extent, they did not do so enough to reduce the increase in their domestic price below the increase that would have occurred in the absence of insulation. For maize, it appears that China, Korea, Indonesia and India insulated enough to reduce the rise in their domestic price relative to the no-insulation scenario, while for edible oils China and Japan appear to have insulated enough to reduce the rise in their domestic price to less than the increase that would have occurred in the absence of insulation. 


\section{Changes in protection in our sample countries}

For the developing countries for which household data are available, the 2006-8 changes in protection to the four key crop products are detailed in Table 4. The table suggests that protection in most developing countries fell during the observed period. The table also includes at the bottom, for comparison, several large countries for which suitable household data are unavailable: their changes in protection are broadly similar to the changes in protection in our sample countries, apart from Egypt and Russia where protection rates appear to have increased for wheat and oils.

\section{Domestic prices with and without insulation}

We can now estimate the changes in domestic prices that that can be attributed to price insulation policies. These domestic price changes, reported in Table 5, take into account two separate simulated price impacts: first, the impact of insulation by the country itself and, second, the insulation by the whole world. The first of these price changes is reported in Table 4 while the second is the estimated change in world prices reported in column 1 of Table 3.

The simulated domestic price impacts of removing insulation in all countries vary considerably across countries and commodities, depending on each country's level of insulation relative to the change in the international price. For example, the domestic price of rice would have fallen more in China as a result of own-country and rest-of-world insulation, but only by 5 percent: its own 37 percent reduction in protection lowered its domestic price relative to the international price, but the latter would have been 52 percent higher with global insulation. Overall for our sample of 30 countries, in 30 percent of cases the domestic price changed in the opposite direction to the country's own change in protection. 


\section{Distribution of price changes due to different actions by developing and developed countries}

With different countries applying different changes in protection during 2006-2008, some countries achieved some degree of insulation of their domestic prices while others experienced higher prices than they would if no country had insulated. The countries that insulated the most vigorously "exported" price increases to the countries that insulated less. These "imports" and "exports" of price increases could have important consequences for poverty. Some advocates of price insulation argue that it can be used by developing countries to shift price increases to highincome countries which are much better placed to manage such shocks. To see whether this was the case in 2006-2008, Figure 2 shows the distribution of price changes due to countries' actions from two perspectives: developed versus developing countries (in light blue), and within each of those country groups (in dark red).

Consider first the impacts of the actions of developed and developing countries acting as two aggregate groups. The light blue color set of bars in each sub-figure shows the magnitude of the value change transmitted between developed and developing countries. That magnitude is determined by the consumption share of each group (the $\mathrm{x}$-axis) and the size of excess insulation (over the international price change). As can be seen, in each case the actions of the developing countries lower the extent of their own price rise at the expense of the developed countries. Only in the case of rice did the impact of the developing countries' actions not lower their own price rise much. This is because rice consumption in developed countries is a tiny share of world consumption and hence little of the rice price increase could be "exported" from those countries.

Second, consider the level of coordination among developing countries' own actions, by focusing on the dark red color bars which show how much of the international price change was distributed within the group by group member actions. In the case of rice, for example, China, 
Indonesia and Bangladesh insulated their markets much more than others, shifting the price increases onto the shoulders of other countries. A similar situation can be observed for the remaining crops, where China alone (plus India in the case of wheat) was successful in lowering the extent of its own domestic price rise — but, in doing so, it put upward pressure on prices in other countries.

\section{Poverty impacts}

Using our sample of 30 developing countries, we can now evaluate the poverty impacts of the hypothetical price changes that would have been associated with the observed levels of price insulation in the period 2006-08. To calculate poverty impacts, we follow the methodology of Ivanic et al. (2012) who measure changes in poverty as a change in the number of people living on less than 1.25 US dollars a day in 2005 PPP dollars. They do so by assuming household real income, $B$, depends on the expenditure required to achieve its initial level of utility, and on the income generated by any farm business it operates:

$$
\text { Equation } 5 \quad B=e(p, w, u)-r(p, w)
$$

where $e(p, w, u)$ is the cost of expenditure; $r(p, w)$ is the revenue from the farm firm (including that which is consumed by the household; $\mathrm{p}$ is a vector of prices; $\mathrm{w}$ is a vector of wage rates; and $\mathrm{u}$ is utility.

Differentiating gives Deaton's net consumption measure:

Equation $6 \quad d B=e_{p} d p-r_{p} d p=z_{p} d p$ 
where $z_{p}$ is the household's net purchases of food. In contrast with Hertel and Winters (2006) and Jacoby (2013), we consider the change in the revenue accruing to the household through the $r_{p} d p$ term, without allocating it into returns to labor and capital, because this allows us to assess the income effects of changes in individual food prices on farm households much more precisely. Because we consider such a short period, we assume that wage rates paid to labor sold outside the farm firms do not respond to changes in food prices. Most studies that allow for a dynamic path of response from commodity price changes to wages find quite small wage impacts in the first year or two (see, for example, Lasco et al, 2008).

This approach only considers the short-run impact of the changes in food prices on households' agricultural sales and food expenditures. That is, we ignore any quantity adjustments (increases in production or changes in consumption) because these are second-order impacts of the price changes. Because elasticities of demand for the staple foods considered are typically quite low the inclusion of second-order impacts on demand is unlikely to have a large impact on the overall welfare impact. While the second-order impacts through changes in supply can be much larger, there is little scope to change quantities supplied in the short run.

Two simulations are reported in Table 6. Starting from the hypothetical price levels representing the world with no insulation in each case, the first simulation shows the implications of the observed changes in trade distortions in all countries. The second scenario assumes that developing and developed countries insulated by the average observed level for that group. These simulations allow us to see whether developing countries were able to shift the price increases onto the industrial countries that are so much better placed to manage the effects of food price shocks, or whether the major redistributions of the price rises were between developing countries. Both sets of results are shown in Table 6 in terms of percentage point 
changes in the initial poverty rates as well as the estimated absolute changes in the number of poor people.

According to the first pair of columns in Table 6, choosing to insulate helped around half of the countries considered ( 13 of the 30 ) to lower the poverty rate relative to the outcome from the initial exogenous international price shock. For many countries that insulated, however, the results in this table suggest that the combined effect of insulation was actually to raise poverty. Based on the second pair of columns, had all developing countries insulated by the average degree of insulation for developing countries, all but five of those thirty countries would have seen more of their people move out of poverty.

Based on the coverage of our sample of global poverty by region and income level, we extrapolate sample poverty changes into poverty estimates at the global, regional and incomegroup level (low, lower-middle and upper-middle income countries). To perform this extrapolation, we assign weights to the countries in the sample to make them represent all countries for their particular income and regional group. With the inclusion of China and India, our sample covers most of the regions and income groups with poverty and especially the "pockets of poverty" among the lower-middle income countries of South Asia and the upper middle-income countries of East Asia where our sample coverage is nearly complete.

Since, as shown in Table 7, our sample covers 76 percent of the world's poor people, we were reasonably confident that it would allow reasonable approximations of the impacts of food price changes on global poverty. To formalize this intuition, we used the weights for the countries included in our sample and for other developing countries for which poverty estimates are available to evaluate the standard error associated with our sample estimates. To do this, we 
performed a Monte Carlo simulation of 10,000 runs in which we simulated normally ${ }^{6}$ and independently distributed poverty changes in the set of 109 developing countries for which poverty estimates are available. In each run, we calculated - using weights equal to each country's share of the global poor population - the poverty change for the whole population and for our sample of thirty countries. We then measured the difference between the sample and the population mean in each period and calculated the variance of this difference over our 10,000 observations. Finally, we calculated the ratio of this variance to the average weighted variance of the sample outcomes, which we find to be equal to 1.47 percent. This implies that on average the standard error of the estimates obtained from our sample is 12 percent of the sample's weighted standard deviation.

The poverty results in Table 6 suggest that the observed level of price insulation most likely did not affect global poverty significantly. Global poverty appears to have risen by 8 million people as a result of insulation, a change that is smaller than the standard error for this estimate of 10 million. Had all developing countries insulated identically at the average level for developing countries so that any effect is due to exporting the price increases to high-income countries, the overall global poverty change would have been a decline of 7 million, which, given a standard error of 8 million, is also not significantly different from zero.

Three partial indicators are also revealing. The first is the effect of the observed changes in domestic prices on poverty. This measure suggests that the observed increases in domestic prices resulted in an increase in global poverty of 80 million people in developing countries living below the $\$ 1.25$ per day poverty line (Table 10) with a standard error of 19 million people. The second measure, which we term the apparent poverty reduction from price insulation, is the

\footnotetext{
${ }^{6}$ We use a standard normal distribution for convenience but the result will be invariant to the choice of variance.
} 
effect of altering trade restrictions on poverty assuming that the international price is unchanged by countries' interventions. This estimate is a reduction of poverty by 82 million people with a standard error of 18 million people. It seems likely that policy makers - particularly in small countries — would focus on this latter measure (shown for individual countries in Table 9) because it does not require a model of policy choice in a world of many countries, and does not require knowledge of the policy responses taken by other countries. For small countries, these numbers are the impact of the country's own price insulation on the poverty rate in their country. For large countries, they overstate the benefits of price insulating policies by failing to take into account the impacts of the country's own insulating policies on the international price.

The third partial measure, which we report in the final two columns of Table 9, is the implications of each country's own insulation on its own poverty rate both directly through its own price insulation, and through the effects of that insulation on world prices. This table shows that while large countries' own insulation (mainly in India, China and Bangladesh) has some adverse implications for poverty by pushing up international price, the size of this impact is generally dwarfed by the domestic impacts of their own insulation. This highlights the collectiveaction problem associated with this form of policy response-for individual countries, insulating frequently appears to make sense as a way to reduce the poverty impacts of world price increases even while it is collectively ineffective.

\section{Some policy implications}

Standard principles of economic policy suggest that the most effective approach in dealing with the poverty consequences of price volatility is via instruments targeted most directly at the problem. This suggests that a social safety net aimed directly at alleviating poverty is likely to 
raise more individuals out of poverty than an indirect policy that operates through market prices facing all consumers, and even more so than one at a country's border since that also affects producer incentives. In some settings pure safety net policies may not be feasible, and nations adopt or consider alternative policies. For example, Gouel and Jean (2012) find that targeted subsidies to domestic storage combined with trade policies yield more poverty reduction for each individual country alone.

The apparent success of some countries in reducing the extent of increase in domestic prices might lead one to encourage or assist other developing countries to achieve the same high degree of price insulation. This would, however, run head-first into the collective action problem: for commodities such as rice, where the market share of developed countries is small, equally successful insulation by all developing countries-both exporters and importers — would be very similar to no insulation at all.

What are the consequences of collective action problems for the effects of policies at different levels - national, regional, or global? If price stabilization were only attainable through price insulation, if all countries had the same responses to price volatility, and if all countries were small, then the collective action problem would need to be addressed at the regional or global level. Each country would, unilaterally, have an incentive to insulate to the same degree. Using rational storage policies as suggested by Gouel and Jean (2012) offers some possibility of diminishing the extent of beggar-thy-neighbor impacts than use of insulating trade policies alone. However, this proposal is very different from the policies observed in the 2008 crisis: global rice stocks - and stocks in most major developing countries — increased rather than decreased during 2007-08, despite extraordinarily high prices. 
The result that the largest developing countries tend to insulate their markets more than other countries raises important questions for their policy makers. That this occurred despite a higher cost to large importing countries than others of unilateral insulating action ${ }^{7}$ is something of a puzzle. Are policy makers taking full account of the impact of their actions on international prices? In the case of food-exporting countries, their insulating action improves their terms of trade but risks alienating their trading partners. Perhaps part of the explanation is that the largest developing countries have historically been close to self-sufficient, and hence their policy makers are not overly worried about developing a reputation as an unreliable exporter-a goal that appears to have contributed to a pressure by farm interests, in such countries as the United States and Australia, against export restrictions.

At the regional level, there may be scope for policy commitments that reduce the adverse impacts of beggar-thy-neighbor policies. If, for instance, regional groups were able to make binding commitments to allow exports to flow even during times of shortage, then this may reduce the deep-seated concerns of policy makers in importing countries about the availability of sufficient importable food in times of crisis. Rice in Asia is the most obvious case in point.

It is understandable that countries depending heavily on the international food market worry that they might be vulnerable to export controls or taxes imposed by their suppliers. At the WTO, many importing countries have put forward proposals for disciplining export barriers (Congo 2001, Japan 2000, Jordan 2001, Korea 2001 and Switzerland 2000). Some of these proposals are far reaching. For example, the Jordan proposal is to ban export restrictions and bind all export taxes at zero. The proposal by Japan involves disciplines similar to those on the

\footnotetext{
${ }^{7}$ The welfare costs of unilaterally reducing the domestic price rise are higher in a food-deficit large country than a small one because such action by a large importing country causes the international price to rise and hence increases the welfare cost of achieving any given reduction in the extent of the rise in the domestic price.
} 
import side, with export restrictions to be replaced by taxes and those export taxes to be bound. Recognizing that importers' concerns about the reliability of supply might inhibit liberalization, some exporting countries have also advocated multilateral limitations on the right to use export restrictions. In the preliminary negotiations on agriculture held between 1999 and 2001 under Article 20 of the Uruguay Round Agreement on agriculture, the Cairns Group (2000) and the United States (2000) put forward proposals for disciplines on export barriers and/or taxes.

The ability of importing countries to lower protection when prices rise is currently unconstrained by WTO rules. Countries with low initial tariffs have little scope to reduce their protection when world prices rise, but they can introduce import subsidies - as indeed some countries did in 2008. If exporting countries were to be restrained by WTO rules from introducing export barriers, however, there would be less reason for tariff reductions by foodimporting countries.

\section{Conclusions}

In this paper, we have analyzed the distributional and poverty impacts of the food price insulation that was observed in the period of 2006-2008 when prices of many staple food items increased sharply. For four major food items — rice, wheat, maize and edible oils—which comprise nearly half of poor people's food expenditure, we have estimated how much the observed insulating actions of more than 100 countries, taken as a whole and individually, affected international and domestic food prices and how much it alleviated an increase in global poverty.

As in other recent studies, we find that the observed patterns of price insulation resulted in such a rise of international prices, one which virtually completely offset the benefits of 
insulation. We also find, however, that developing countries as a group insulated more than developed countries and, as a result, parts of the price increases were "exported" to developed countries. This pattern of insulation applies to all four commodities considered in this study, but least so in the case of rice because developed countries represent only a tiny portion of global rice consumption. Nonetheless, the price increase absorbed by developed countries was so small that its implication for global poverty appears negligible.

Our results highlight the seriousness of the problem of rapid increases in food prices in the 2006-2008 period. We find that the rise in poverty resulting from the increases in the domestic prices of the four commodities considered in this paper was 80 million people. For many countries, price insulation appeared to be an effective policy for dealing with this challenge. We estimate that the changes in trade policies (mostly reductions in protection) would have reduced poverty by around 82 million if these policies had been adopted with no changes in international prices. However, the adoption of these insulating prices caused substantial increases in international prices, making them much less effective than they appeared in reducing the poverty impacts of the initial increases in world prices. These results highlight an extremely important collective action problem - policies of insulation that are effective for many individual countries are ineffective for developing countries as a group, because both exporters and importers so respond.

A number of caveats to this analysis need to be kept in mind. One is that we have examined the price effects for just four food items. Including all food items is unlikely to alter the main conclusions, though, because the four included items are so important within the set of traded food products for which price insulation plays a major role. Another caveat is that we have not taken account of any indirect effects on poor households that come via factor markets. 
In agrarian economies with the vast majority of workers employed in agriculture, an increase in farm product prices may raise unskilled wages, although much of this effect may take longer than the short period we consider. That would lower the adverse impact on landless laborers of higher food prices (although we have not found this channel of effect to change the results substantially in earlier work in this vein—see Ivanic and Martin, 2008 and Ivanic et al, 2012).

The literature suggests that social safety net policies can generate larger reductions in poverty, with fewer by-product distortions, than $n^{\text {th }}$-best trade policy instruments that are used for social protection. ${ }^{8}$ They could take the form of targeted income supplements to only the most vulnerable households, and only while the price spike lasts. The potential of these approaches is now much greater than it was just a few years ago, thanks to the digital information and communication technology (ICT) revolution. In the past it has often been claimed that such payments are unaffordable in poor countries because of the fiscal outlay involved and the high cost of administering such handouts. However, recall that in roughly half the cases considered above, governments reduced their trade tax rates or paid import subsidies, so even these trade interventions frequently required budget resources — as did the replacement in many cases of non-prohibitive export taxes with bans. In any case, the option of using value-added taxes in place of trade taxes to raise government revenue has become common practice in even lowincome countries over the past decade or two (Besley and Persson 2013). Moreover, the ICT revolution has made it possible for conditional cash transfers to be provided electronically as direct assistance to even remote and small households, and even to the most vulnerable members of those households (typically women and their young children). True, if those targeted have a greater propensity to spend on food than those being taxed to fund the transfers, they would

\footnotetext{
${ }^{8}$ Indeed conditional cash transfers can contribute not only to equity but can also enhance economic growth. See Alderman and Yemtsov (2013).
} 
boost the global demand for food and hence there would still be a beggar-thy-neighbor impact on international prices (as stressed by Do et al, 2013). Almost certainly, however, that would be far smaller than the impact generated by the much blunter approach of altering trade restrictions. 


\section{References}

Alderman, H. and R. Yemtsov (2013), 'How Can Safety Nets Contribute to Economic Growth?', Policy Research Working Paper 6437, World Bank, Washington DC, May.

Anderson, K. (2009), Distortions to Agricultural Incentives: a Global Perspective 1955-2007, Palgrave MacMillan and the World Bank, New York and Washington DC.

Anderson, K. and S. Nelgen (2012), 'Agricultural Trade Distortions During the Global Financial Crisis', Oxford Review of Economic Policy 28(2): 235-60, Summer.

Anderson, K. and S. Nelgen (2013), Updated National and Global Estimates of Distortions to Agricultural Incentives, 1955 to 2011, Database at www.worldbank.org/agdistortions.

Besley, T.J. and T. Persson (2013), 'Taxation and Development', CEPR Discussion Paper 9307, London, January. (Forthcoming in Handbook of Public Economics, edited by A.

Auerbach, R. Chetty, M. Feldstein and E. Saez, Amsterdam: Elsevier.)

Cairns Group (2000) 'WTO Negotiations on agriculture-Cairns group negotiating proposal:

Export Restrictions and Taxes’ World Trade Organization, 21 Dec G/AG/NG/W/93.

Congo (2001), 'Negotiating Proposals by the Democratic Republic of the Congo', World Trade Organization, Geneva, 12 March, G/AG/NG/W/135.

Deaton, A. (1989), 'Household Survey Data and Pricing Policies in Developing Countries', World Bank Economic Review 3(2): 183-210.

Do, Q.-T., A.L. Levchenko and M. Ravallion (2013), 'Coping with Food Price Shocks: Trade versus Social Protection Policies', Policy Research Working Paper 6448, World Bank, Washington DC, May. (Revision of a paper presented at the NBER Conference on the Economics of Food Price Volatility, Seattle WA, 15-16 August 2012.) 
Gouel, C. and S. Jean (2012), 'Optimal Food Price Stabilization in a Small Open Developing Country', Policy Research Working Paper 5943, World Bank, Washington DC.

Pursell, G., Gulati, A. and Gupta, K. (2009), 'India' in Anderson, K. and Martin, W. eds. Distortions to Agricultural Incentives in Asia, The World Bank, Washington DC.

Hertel, T. and Winters, L.A. (2006), Poverty and the WTO: Impacts of the Doha Development Agenda, Palgrave MacMillan and the World Bank, New York and Washington DC.

Ivanic, M. and W. Martin (2008), 'Implications of Higher Global Food Prices for Poverty in Low-Income Countries’ Agricultural Economics 39:405-16.

Ivanic, M., W. Martin and H. Zaman (2012), 'Estimating the short-run poverty impacts of the 2010 surge in food prices', World Development 40(11):2302-17..

Jacoby, H. (2013), Food Prices, Wages, and Welfare in Rural India, Policy Research Working Paper 6412, World Bank, Washington DC.

Japan (2000), 'Negotiating Proposal by Japan on WTO Agricultural Negotiations', World Trade Organization, Geneva, 21 December, G/AG/NG/W/91.

Jordan (2001), 'WTO Agriculture Negotiations: Proposal by Jordan', World Trade Organization, Geneva, 21 March, G/AG/NG/W/140.

Korea (2001), 'Proposal for WTO Negotiations on Agriculture', World Trade Organization, Geneva, 9 January, G/AG/NG/W/98.

Lasco, C., Myers, R. and Bernsten, R. (2008), 'Dynamics of rice prices and agricultural wages in the Philippines', Agricultural Economics 38:339-48.

Martin, W. and K. Anderson (2012), 'Export Restrictions and Price Insulation During Commodity Price Booms', American Journal of Agricultural Economics 94(2): 422-27. 
Ravallion, M., S. Chen and P. Sangraula (2007), 'New Evidence on the Urbanization of Poverty', Population and Development Review 33(4): 667-702.

Switzerland (2000), 'WTO: Negotiations on Agriculture: Proposal by Switzerland', World Trade Organization, Geneva, 21 December, G/AG/NG/W/94.

Timmer, C.P. (2010), 'Reflections on Past Food Prices’ Food Policy 35: 1-11.

United States (2000), 'Proposal for Comprehensive Long Term Agricultural Trade Reform', World Trade Organization, Geneva, 23 June, G/AG/NG/W/15.

World Bank (2007), World Development Report 2008: Agriculture for Development, Washington DC: World Bank. 
Table 1: Food expenditures of people living on less than $\$ 1.25$ per day, 30 developing countries, 2001-2010 ${ }^{11}$

\begin{tabular}{|c|c|c|c|c|c|c|c|c|c|c|c|}
\hline & & & & \multicolumn{8}{|c|}{ Average net share in expenditure of the poor, $\%$ of total } \\
\hline & 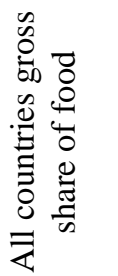 & 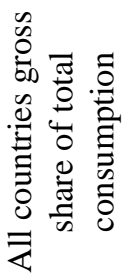 & 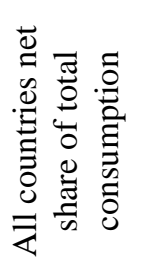 & 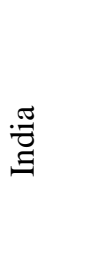 & $\underset{\text { U }}{\stackrel{\Xi}{\Xi}}$ & 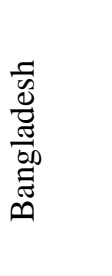 & 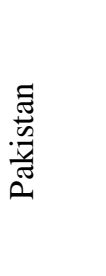 & 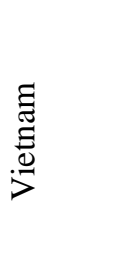 & 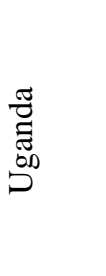 & 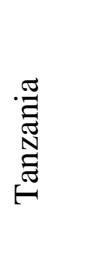 & $\begin{array}{l}. \frac{\pi}{\omega} \\
\stackrel{0}{0} \\
\frac{0}{0} \\
\Xi\end{array}$ \\
\hline Total & 100.0 & 60.8 & 37.0 & 59.7 & 26.2 & 26.1 & 37.8 & -15.6 & 15.2 & 33.4 & 32.7 \\
\hline Rice (+ processed) & 22.4 & 13.9 & 8.2 & 14.7 & 5.6 & 5.0 & 1.7 & -9.3 & 0.1 & 2.8 & 2.6 \\
\hline Other food & 15.6 & 9.7 & 7.6 & 9.9 & 7.5 & 7.7 & 4.4 & 3.5 & 1.6 & 7.9 & 18.9 \\
\hline Vegetables & 15.3 & 9.3 & 4.5 & 11.0 & 0.5 & 4.6 & 6.2 & -3.2 & 4.5 & 5.7 & 1.7 \\
\hline Meats & 9.1 & 5.4 & 2.4 & 1.8 & 9.6 & -0.3 & 1.3 & -1.7 & 2.1 & 0.3 & -0.6 \\
\hline Wheat (+ processed) & 8.4 & 5.0 & 3.5 & 4.6 & 3.4 & 0.6 & 10.4 & 1.3 & 0.2 & 1.8 & 0.0 \\
\hline Oilseeds and edible oils & 6.5 & 3.9 & 3.4 & 5.2 & 0.2 & 2.6 & 4.5 & 1.0 & 1.4 & 2.7 & 3.9 \\
\hline Fish and fish products & 6.3 & 3.8 & 2.5 & 1.6 & 3.6 & 5.0 & 0.3 & -1.7 & 2.1 & 3.3 & 2.7 \\
\hline Milk and dairy products & 5.6 & 3.3 & 2.9 & 6.1 & 0.0 & -0.3 & 3.4 & 0.7 & 0.3 & -0.1 & 0.5 \\
\hline Maize and other grains & 4.1 & 2.6 & -0.5 & 1.5 & -5.5 & -0.1 & 0.2 & -4.1 & 1.2 & 6.3 & 0.0 \\
\hline Fruits & 3.9 & 2.3 & 1.1 & 0.9 & 1.4 & 1.0 & 1.0 & -1.2 & -0.5 & -0.3 & -0.6 \\
\hline Sugar & 2.7 & 1.7 & 1.5 & 2.3 & 0.0 & 0.2 & 4.5 & -0.9 & 2.3 & 3.1 & 3.5 \\
\hline
\end{tabular}

Sources: Authors' calculations

\footnotetext{
${ }^{11}$ Weighted averages across the 30 developing countries are calculated using poor populations as weights. The $\$ 1.25$ per day income level (2005 purchasing power parity) includes own-food consumption. Net share in expenditure refers to consumption of food less sales of food as a share of total expenditure, including own-food consumption. For the list of developing countries and their survey dates, see footnote 1 of the text.
} 
Table 2: Changes in domestic food and non-food prices, in nominal local currency terms, 2006$08, \%$

\begin{tabular}{|c|c|c|c|c|c|}
\hline & Rice & Wheat & Maize & Edible oils & Non-food \\
\hline Albania & - & 72.3 & 63.7 & 26 & 5.8 \\
\hline Armenia & - & 84.5 & - & - & 11.1 \\
\hline Bangladesh & 25.2 & 4.7 & 31.4 & 0.5 & 14.2 \\
\hline Belize & 10.5 & - & 11.7 & 7.5 & 6.5 \\
\hline Cambodia & 45.6 & - & 98 & 58.1 & 31.6 \\
\hline China & 35.4 & 37.5 & 41.8 & -17.9 & 1.4 \\
\hline Cote d'Ivoire & 64 & - & 39.7 & 46.3 & -0.8 \\
\hline Ecuador & 76.4 & 124.5 & 140.3 & 18.5 & 7.4 \\
\hline Guatemala & 75.6 & - & 29.6 & - & 10.9 \\
\hline India & 48.9 & 26.6 & 14.1 & 36.8 & 9.4 \\
\hline Indonesia & 22.7 & - & 22.2 & 80.1 & 4.8 \\
\hline Malawi & 40.4 & 26.3 & 42.6 & 19.7 & 23.7 \\
\hline Moldova & - & 72.8 & 53.6 & 43.3 & 25.2 \\
\hline Mongolia & - & 111.3 & - & - & 22.1 \\
\hline Nepal & 10.7 & 28 & 21.6 & 0.1 & 14.9 \\
\hline Nicaragua & 34.1 & - & 41.7 & 7.7 & 14.3 \\
\hline Niger & 26.8 & 28.1 & 28.4 & 27.4 & 4.7 \\
\hline Nigeria & 22.8 & 39.6 & 57.4 & 29.4 & 17.1 \\
\hline Pakistan & -2.6 & -9.3 & -8.2 & -2.3 & 21.1 \\
\hline Panama & 45.5 & - & 57.5 & - & 7.5 \\
\hline Peru & 118.1 & 100.5 & 54.4 & 37.2 & 6 \\
\hline Rwanda & -52.7 & 22.3 & 30.5 & 40.1 & 14.8 \\
\hline Sri Lanka & 120.9 & - & 74.7 & 47 & 6.8 \\
\hline Tajikistan & -47.9 & 65.8 & - & - & 7.2 \\
\hline Tanzania & 115.1 & 102.8 & 25 & - & 13.8 \\
\hline Timor-Leste & - & - & - & - & 6.8 \\
\hline Uganda & 22.2 & - & 33 & - & 16.3 \\
\hline Viet Nam & 83.1 & - & - & - & 11.1 \\
\hline Yemen & - & 61.3 & 50.2 & - & 15.5 \\
\hline Zambia & 42.7 & 17.8 & 27.7 & - & 30.6 \\
\hline
\end{tabular}

Sources: Authors' calculations based on the World Bank's Distortions to Agricultural Incentives database at www.worldbank.org/agdistortions, the FAO's producer price data, CPI for all consumption and non-foods, and its GIEWS survey data at www.fao.org. 
Table 3: Impacts of domestic market insulation on international prices, 2006-08

\begin{tabular}{|l|c|c|c|c|c|}
\hline & $\begin{array}{c}\text { Assuming no } \\
\text { supply response }\end{array}$ & $\begin{array}{c}\text { Assuming } \\
\text { es=1 and } \\
\text { ed=-0.2. } \%\end{array}$ & $\begin{array}{c}\text { Share of world } \\
\text { consumption } \\
\text { covered, } \%\end{array}$ & $\begin{array}{c}\text { Share of world } \\
\text { production } \\
\text { covered, \% }\end{array}$ & $\begin{array}{c}\text { Number of } \\
\text { countries } \\
\text { included }\end{array}$ \\
\hline Edible oils & 30.9 & 25.5 & 95 & 97 & 96 \\
\hline Maize & 18 & 17.3 & 93.8 & 97.2 & 103 \\
\hline Rice & 51.9 & 50.5 & 91.8 & 93.9 & 82 \\
\hline Wheat & 17.6 & 16.2 & 92.9 & 97.2 & 87 \\
\hline
\end{tabular}

Source: Authors' calculations 
Table 4: Observed change in protection, 2006-08, percent

\begin{tabular}{|l|c|c|c|c|}
\hline & Rice & Wheat & Maize & Edible oils \\
\hline Albania & - & -21.5 & -16.5 & -39.2 \\
\hline Armenia & - & 5.2 & - & - \\
\hline Bangladesh & -41.3 & -38.3 & -27.5 & 0.5 \\
\hline Belize & -40.7 & - & -37.3 & -30.1 \\
\hline Cambodia & -26.9 & - & 0.8 & -17.6 \\
\hline China & -37.4 & -23.5 & -36.1 & -52.2 \\
\hline Cote d'Ivoire & -23.1 & - & -13.4 & -17.2 \\
\hline Ecuador & -5.9 & -2.9 & 23.7 & 10.1 \\
\hline Guatemala & -8 & - & -33.7 & - \\
\hline India & -30.2 & -25.4 & -37.7 & -20.7 \\
\hline Indonesia & -44.1 & - & -42.1 & -13.1 \\
\hline Malawi & 3.5 & -29.6 & 145.6 & -3.1 \\
\hline Moldova & - & -27 & -21.4 & 0.4 \\
\hline Mongolia & - & 6.2 & - & - \\
\hline Nepal & -60.5 & -33.2 & -10.7 & -0.2 \\
\hline Nicaragua & -37.1 & - & -22.6 & -26.5 \\
\hline Niger & -7.7 & -6.8 & -14.5 & -7.7 \\
\hline Nigeria & -42.4 & -52.6 & -14.1 & -23.5 \\
\hline Pakistan & -54.3 & -46.6 & -49.8 & -33.8 \\
\hline Panama & -8.7 & - & -22.9 & - \\
\hline Peru & 16.6 & -8.3 & -22.5 & -4.6 \\
\hline Rwanda & -55.7 & -31.6 & 161.1 & -6.3 \\
\hline Sri Lanka & 3.6 & - & 14.7 & 5.1 \\
\hline Tajikistan & -61.7 & -48.7 & - & - \\
\hline Tanzania & 0.9 & 19.5 & -31.8 & - \\
\hline Uganda & -42.7 & - & -27.4 & - \\
\hline Viet Nam & -15.9 & - & - & - \\
\hline Yemen & - & -39.9 & -24 & - \\
\hline Zambia & -21.5 & -32.2 & 67.7 & - \\
Brazil & -21.6 & -0.1 & 0.9 & 1.9 \\
\hline Egypt & -32.7 & 40.8 & -24.5 & 31 \\
\hline EU & 4.4 & -0 & -14.4 & -5.1 \\
\hline Philippines & -26.7 & - & -22 & -8.9 \\
\hline Russian Federation & -18.1 & 6.7 & -17.5 & 17.6 \\
\hline USA & -0.1 & -0 & -0 & -15.1 \\
\hline Source Auts & & & & \\
\hline
\end{tabular}

Source: Authors' calculations 
Table 5: Implications of all countries' insulation for domestic prices, 2006-08 (percent)

\begin{tabular}{|c|c|c|c|c|}
\hline & Rice & Wheat & Maize & Edible oils \\
\hline Albania & - & -7.6 & -1.5 & -20.4 \\
\hline Armenia & - & 23.8 & - & - \\
\hline Bangladesh & -10.9 & -27.5 & -14.4 & 31.5 \\
\hline Belize & -9.9 & - & -26 & -8.4 \\
\hline Cambodia & 11.1 & - & 19 & 7.9 \\
\hline China & -4.9 & -10 & -24.6 & -37.4 \\
\hline Cote d'Ivoire & 16.8 & - & 2.1 & 8.4 \\
\hline Ecuador & 42.9 & 14.2 & 46 & 44.1 \\
\hline Guatemala & 39.7 & - & -21.8 & - \\
\hline India & 6.1 & -12.3 & -26.5 & 3.8 \\
\hline Indonesia & -15.1 & - & -31.7 & 13.8 \\
\hline Malawi & 57.2 & -17.2 & 189.7 & 26.9 \\
\hline Moldova & - & -14.1 & -7.3 & 31.4 \\
\hline Mongolia & - & 25 & - & - \\
\hline Nepal & -40 & -21.4 & 5.3 & 30.6 \\
\hline Nicaragua & -4.5 & - & -8.7 & -3.8 \\
\hline Niger & 40.2 & 9.7 & 0.8 & 20.8 \\
\hline Nigeria & -12.6 & -44.2 & 1.4 & 0.2 \\
\hline Pakistan & -30.6 & -37.1 & -40.8 & -13.3 \\
\hline Panama & 38.7 & - & -9.1 & - \\
\hline Peru & 77 & 7.9 & -8.5 & 24.9 \\
\hline Rwanda & -32.7 & -19.5 & 208 & 22.6 \\
\hline Sri Lanka & 57.3 & - & 35.3 & 37.6 \\
\hline Tajikistan & -41.8 & -39.6 & - & - \\
\hline Tanzania & 53.2 & 40.5 & -19.5 & - \\
\hline Uganda & -12.9 & - & -14.3 & - \\
\hline Viet Nam & 27.7 & - & - & - \\
\hline Yemen & - & -29.2 & -10.3 & - \\
\hline Zambia & 19.3 & -20.2 & 97.8 & - \\
\hline Brazil & 19 & 17.6 & 19 & 33.4 \\
\hline Egypt & 2.2 & 65.6 & -10.9 & 71.4 \\
\hline $\mathrm{EU}$ & 58.6 & 17.6 & 1 & 24.3 \\
\hline Philippines & 11.3 & - & -8 & 19.3 \\
\hline Russian Federation & 24.4 & 25.6 & -2.7 & 54 \\
\hline USA & 51.7 & 17.6 & 17.9 & 11.1 \\
\hline
\end{tabular}

Source: Authors' calculations 
Table 6: Changes in poverty due to observed insulation, or from developing countries using a uniform rate of insulation, ${ }^{1} 2006-08$ (percent)

\begin{tabular}{|c|c|c|c|c|}
\hline & \multicolumn{2}{|c|}{ Observed insulation } & \multicolumn{2}{|c|}{$\begin{array}{l}\text { Uniform insulation in developing } \\
\text { countries }\end{array}$} \\
\hline & $\begin{array}{c}\text { Change in } \\
\text { poverty } \\
\text { headcount }(\%)\end{array}$ & $\begin{array}{c}\text { Change in } \\
\text { number of poor } \\
\text { (thousand) }\end{array}$ & $\begin{array}{c}\text { Change in } \\
\text { poverty } \\
\text { headcount }(\%)\end{array}$ & $\begin{array}{l}\text { Change in number } \\
\text { of poor (thousand) }\end{array}$ \\
\hline Albania & -0.1 & -2 & -0.1 & -2 \\
\hline Armenia & 0.2 & 7 & -0.1 & -4 \\
\hline Bangladesh & 0.8 & 1,235 & -0.1 & -146 \\
\hline Belize & -0.1 & 0 & -0.2 & -1 \\
\hline China & 0.3 & 3,620 & 0.1 & 1,718 \\
\hline Cote D'Ivoire & 1 & 194 & -0.2 & -35 \\
\hline Ecuador & 0.6 & 89 & 0.0 & 1 \\
\hline Guatemala & -0.1 & -16 & -0.3 & -42 \\
\hline Indonesia & 0 & 104 & 0.0 & -7 \\
\hline India & 0.4 & 4,380 & -0.4 & $-5,247$ \\
\hline Cambodia & -1.7 & -246 & 0.1 & 12 \\
\hline Sri Lanka & 2.2 & 467 & -0.2 & -33 \\
\hline Moldova & -0.1 & -3 & -0.2 & -8 \\
\hline Mongolia & 1.2 & 33 & -0.3 & -8 \\
\hline Malawi & 2.4 & 362 & -0.3 & -52 \\
\hline Niger & 1 & 166 & -0.1 & -14 \\
\hline Nigeria & -0.7 & $-1,158$ & -0.1 & -243 \\
\hline Nicaragua & -0.1 & -5 & 0.0 & -2 \\
\hline Nepal & -0.5 & -150 & -0.1 & -22 \\
\hline Pakistan & -3.3 & $-5,898$ & -0.7 & $-1,273$ \\
\hline Panama & 0.3 & 11 & 0.0 & -2 \\
\hline Peru & 0.9 & 256 & -0.1 & -21 \\
\hline Rwanda & 0.6 & 66 & -0.1 & -13 \\
\hline Tajikistan & -1.2 & -86 & -0.4 & -25 \\
\hline Timor-Leste & 0 & 0 & 0.0 & 0 \\
\hline Tanzania & 0.6 & 292 & -0.4 & -169 \\
\hline Uganda & 0 & -2 & -0.1 & -18 \\
\hline Viet Nam & -0.4 & -381 & 0.1 & 78 \\
\hline Yemen & -1.9 & -483 & -0.5 & -127 \\
\hline Zambia & -1.9 & -250 & 0.0 & 1 \\
\hline
\end{tabular}

Source: Authors' calculations 
Table 7: Sample coverage of the developing countries' $\$ 1.25$ per day poor people, by region and income levels

\begin{tabular}{|c|c|c|c|c|c|c|c|c|}
\hline & \multicolumn{6}{|c|}{ Region } & \multirow[t]{2}{*}{ World } \\
\hline & & $\begin{array}{c}\text { East Asia \& } \\
\text { Pacific }\end{array}$ & $\begin{array}{c}\text { Europe \& } \\
\text { Central Asia }\end{array}$ & $\begin{array}{c}\text { Latin } \\
\text { America }\end{array}$ & $\begin{array}{c}\text { Middle East } \\
\text { \& North } \\
\text { Africa }\end{array}$ & South Asia & $\begin{array}{c}\text { Sub-Saharan } \\
\text { Africa }\end{array}$ & \\
\hline \multirow[t]{4}{*}{ Low- income } & Poor population, mil & 3.3 & 0.8 & 6.2 & - & 72.7 & 264.6 & 347.6 \\
\hline & Sample coverage, mil & 3.3 & 0.5 & 0.0 & - & 72.7 & 69.8 & 146.3 \\
\hline & Sample coverage, share & $100 \%$ & $63 \%$ & $0 \%$ & - & $100 \%$ & $26 \%$ & $42 \%$ \\
\hline & Weight & 1.0 & 1.7 & - & - & 1.0 & 3.8 & - \\
\hline \multirow{4}{*}{$\begin{array}{l}\text { Lower-middle } \\
\text { income }\end{array}$} & Poor population, mil & 81.8 & 0.8 & 6.8 & 8.0 & 444.3 & 148.3 & 690 \\
\hline & Sample coverage, mil & 59.6 & 0.1 & 2.7 & 4.3 & 444.3 & 124.5 & 635.5 \\
\hline & Sample coverage, share & $73 \%$ & $13 \%$ & $40 \%$ & $54 \%$ & $100 \%$ & $84 \%$ & $92 \%$ \\
\hline & Weight & 1.4 & 10.7 & 2.5 & 1.8 & 1.0 & 1.2 & - \\
\hline \multirow{4}{*}{$\begin{array}{l}\text { Upper-middle } \\
\text { income }\end{array}$} & Poor population, mil & 175.8 & 1.4 & 22.6 & 3.7 & - & 19.1 & 222.6 \\
\hline & Sample coverage, mil & 175.5 & 0.0 & 2.4 & 0.0 & - & 0.0 & 177.9 \\
\hline & Sample coverage, share & $100 \%$ & $0 \%$ & $11 \%$ & $0 \%$ & - & $0 \%$ & $80 \%$ \\
\hline & Weight & 1.0 & - & 9.6 & - & - & - & - \\
\hline \multirow[t]{3}{*}{ World } & Poor population, mil & 260.9 & 3.0 & 35.6 & 11.7 & 517.0 & 432.0 & 1260.2 \\
\hline & Sample coverage, mil & 238.4 & 0.6 & 4.9 & 4.3 & 517.0 & 194.3 & 959.7 \\
\hline & Sample coverage, share & $91 \%$ & $20 \%$ & $14 \%$ & $37 \%$ & $100 \%$ & $45 \%$ & $76 \%$ \\
\hline
\end{tabular}

Source: Authors' calculations using World Bank income categories 
Table 8: Extrapolated global poverty implications of insulation (in millions)

\begin{tabular}{|l|c|c|}
\hline & Mean estimate & Standard deviation \\
\hline Observed insulation & 7.5 & 10.3 \\
\hline $\begin{array}{l}\text { Uniform insulation in developing countries (at } \\
\text { observed global insulation level) }\end{array}$ & -7.2 & 8.4 \\
\hline
\end{tabular}


Table 9: Partial changes in poverty due to changes in domestic prices and in domestic protection in 2006-08, percent

\begin{tabular}{|c|c|c|c|c|c|c|}
\hline & \multicolumn{2}{|c|}{$\begin{array}{l}\text { Insulation (assuming no } \\
\text { implication for global } \\
\text { prices) }\end{array}$} & \multicolumn{2}{|c|}{$\begin{array}{l}\text { Observed changes in } \\
\text { domestic prices }\end{array}$} & \multicolumn{2}{|c|}{$\begin{array}{l}\text { Insulation (assuming no } \\
\text { implication for global prices other } \\
\text { than own impacts on world price) }\end{array}$} \\
\hline & $\begin{array}{c}\text { Change in } \\
\text { poverty } \\
\text { headcount } \\
(\%)\end{array}$ & $\begin{array}{c}\text { Change in } \\
\text { number of } \\
\text { poor } \\
\text { (thousand) }\end{array}$ & $\begin{array}{c}\text { Change in } \\
\text { poverty } \\
\text { headcount } \\
(\%)\end{array}$ & $\begin{array}{c}\text { Change in } \\
\text { number of } \\
\text { poor } \\
\text { (thousand) }\end{array}$ & $\begin{array}{c}\text { Change in } \\
\text { poverty } \\
\text { headcount } \\
(\%)\end{array}$ & $\begin{array}{l}\text { Change in } \\
\text { number of poor } \\
\text { (thousand) }\end{array}$ \\
\hline Albania & -0.2 & -7 & 0.6 & 18 & -0.2 & -7 \\
\hline Armenia & -0.1 & -2 & 0.6 & 18 & -0.1 & -2 \\
\hline Bangladesh & -0.6 & -842 & -0.3 & -434 & -0.6 & -902 \\
\hline Belize & -0.6 & -2 & 0 & 0 & -0.6 & -2 \\
\hline China & -0.4 & $-5,710$ & 0.3 & 3,967 & -0.3 & $-4,442$ \\
\hline Cote D'Ivoire & -1 & -198 & 3.9 & 796 & -1 & -198 \\
\hline Ecuador & -0.1 & -15 & 0.6 & 83 & -0.1 & -15 \\
\hline Guatemala & -0.5 & -74 & 0.4 & 52 & -0.5 & -74 \\
\hline Indonesia & 0.7 & 1,579 & 0.8 & 1,921 & 0.5 & 1,319 \\
\hline India & -4.8 & $-59,043$ & 4.7 & 58,722 & -4.3 & $-52,843$ \\
\hline Cambodia & 6.1 & 875 & -1.7 & -238 & 6.1 & 871 \\
\hline Sri Lanka & -0.3 & -55 & 4.6 & 968 & -0.3 & -55 \\
\hline Moldova & -1 & -37 & 1.2 & 43 & -1 & -37 \\
\hline Mongolia & -0.5 & -14 & 4.4 & 123 & -0.5 & -14 \\
\hline Malawi & 0.7 & 105 & 0.2 & 31 & 0.7 & 105 \\
\hline Niger & -0.5 & -73 & 1 & 159 & -0.5 & -73 \\
\hline Nigeria & -2.7 & $-4,377$ & 0.5 & 830 & -2.7 & $-4,329$ \\
\hline Nicaragua & -1.3 & -75 & 0.2 & 9 & -1.3 & -75 \\
\hline Nepal & -1.3 & -409 & 0 & -12 & -1.4 & -413 \\
\hline Pakistan & -5.6 & $-9,936$ & -2.6 & $-4,600$ & -5.6 & $-9,845$ \\
\hline Panama & -0.1 & -4 & 0.2 & 8 & -0.1 & -4 \\
\hline Peru & 0 & -14 & 2.5 & 725 & 0 & -14 \\
\hline Rwanda & 0 & 1 & 0 & 4 & 0 & 2 \\
\hline Tajikistan & -1.8 & -127 & 0.6 & 43 & -1.8 & -127 \\
\hline Timor-Leste & 0 & 0 & 0 & 0 & 0 & 0 \\
\hline Tanzania & -0.9 & -433 & 2.4 & 1,128 & -0.9 & -433 \\
\hline Uganda & -0.1 & -38 & 0 & 8 & -0.1 & -38 \\
\hline Viet Nam & 2.9 & 2,583 & -0.1 & -60 & 2.9 & 2,553 \\
\hline Yemen & -3.2 & -799 & 2.7 & 682 & -3.2 & -796 \\
\hline Zambia & -1.5 & -197 & -0.1 & -12 & -1.5 & -197 \\
\hline
\end{tabular}

Source: Authors' calculations 
Table 10: Extrapolated global poverty estimates (in millions)

\begin{tabular}{|l|c|c|}
\hline & Mean estimate & Standard deviation \\
\hline Observed change in domestic prices & 80.2 & 18.9 \\
\hline Insulation (assuming no implications for global price) & -81.6 & 18.4 \\
\hline
\end{tabular}


Figure 1: Contribution of countries' insulation to global price changes
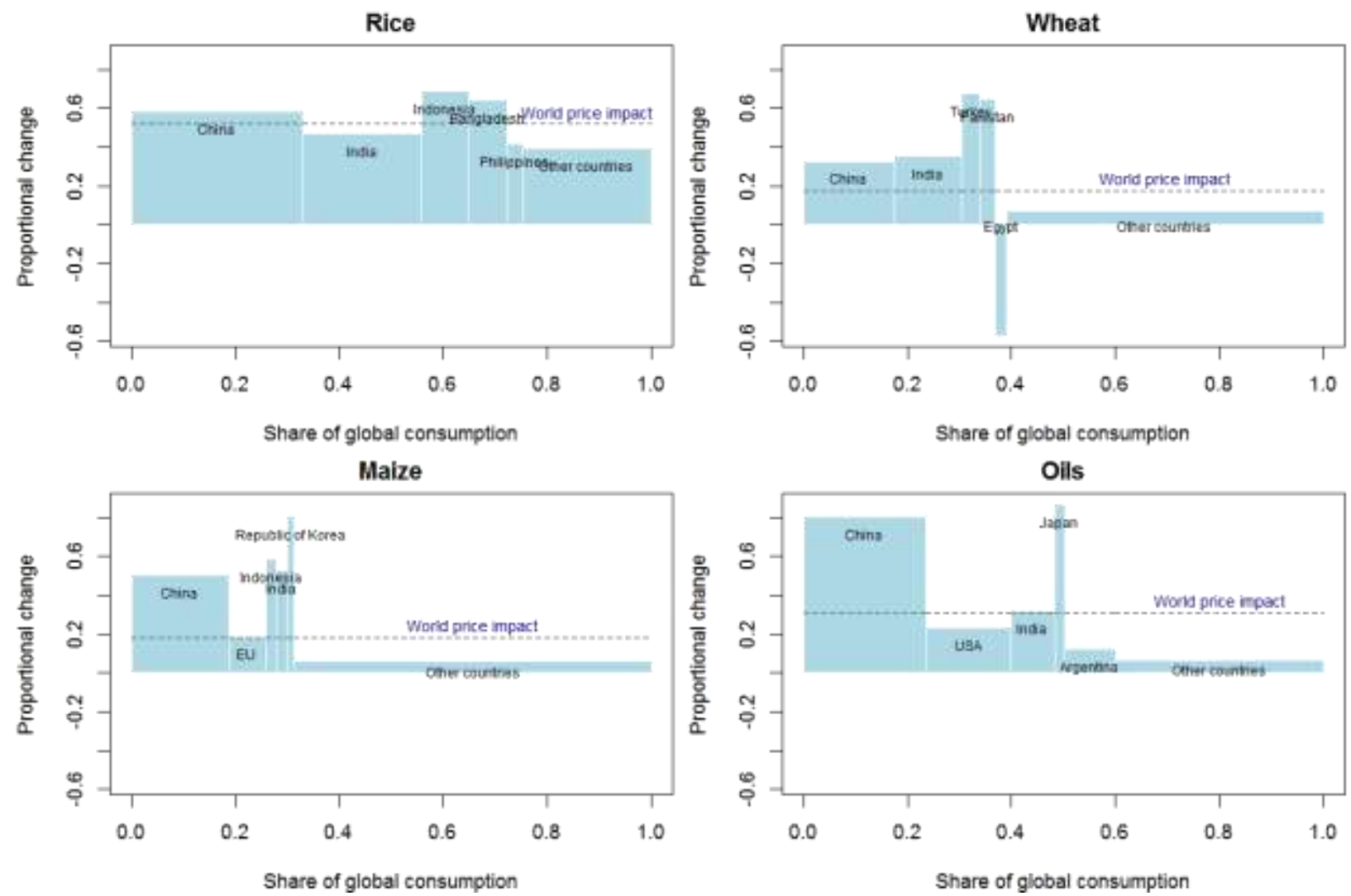

Source: Authors' calculations. 'Protection change' is the negative of the proportional change in $(1+t)$, estimated using the World Bank Distortions to Agricultural Incentives database, supplemented with data from FAOSTAT and FAO's GIEWS database. Global consumption shares at international prices are derived from the FAO's Commodity Balance Sheet database. 
Figure 2: The distribution of price changes due to the observed insulation between developed and developing country groups and within each group
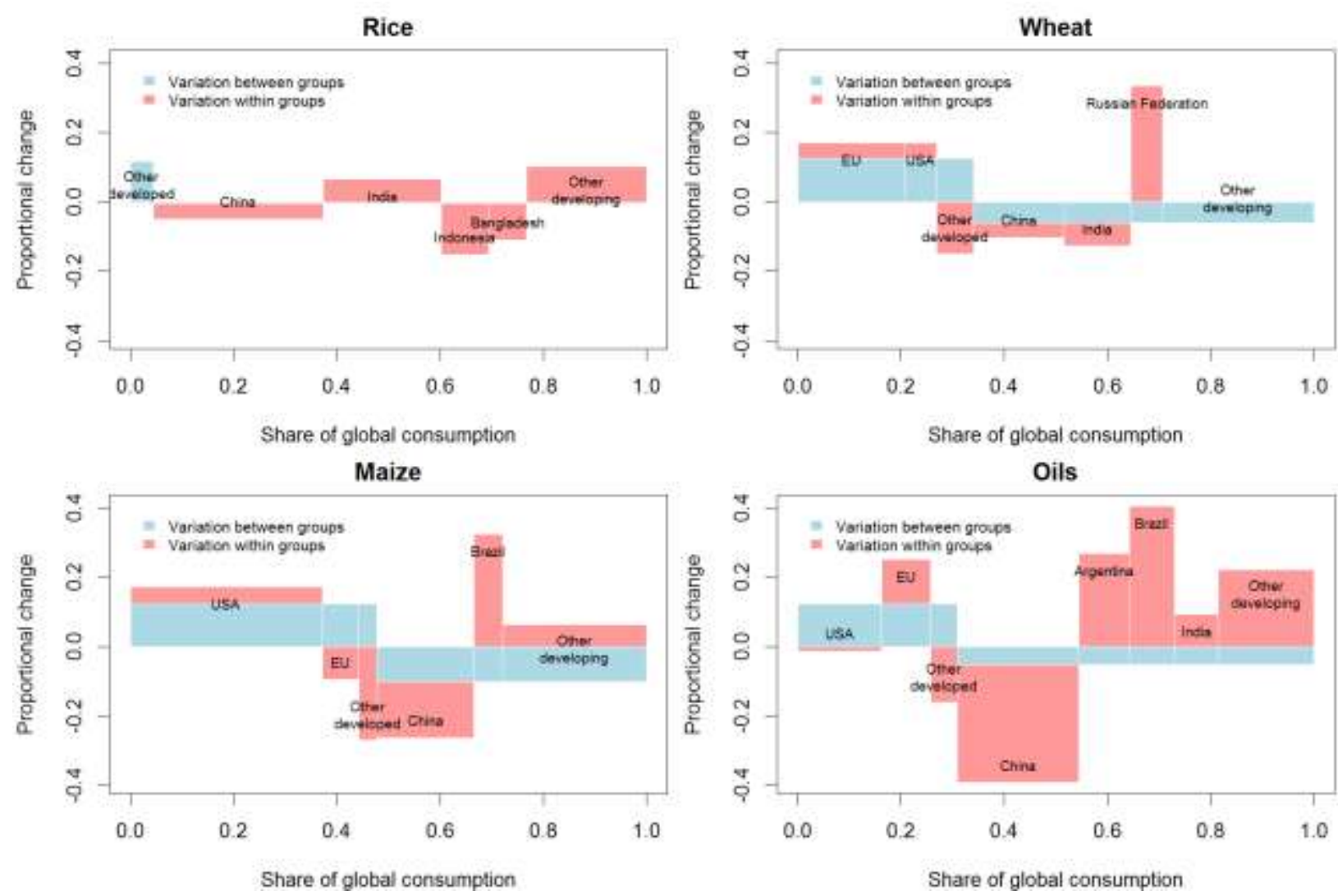

Source: Authors' calculations 


\section{Appendix}

The changes in domestic and border prices for the four key food items are compiled for 103 countries that together account for more than 90 percent of the world market for each of rice, wheat, maize and edible oils. For the present analysis, data are required on changes in domestic and international prices for a set of countries that cover a very large fraction of world consumption, plus estimates of changes in protection in the set of countries for which we have detailed data on production and consumption of each food at the household level. The Distortions to Agricultural Incentives (DAI) database (Anderson and Nelgen 2013) provides annual estimates of agricultural price distortions in 82 countries that are most important in influencing world prices. Because the DAI database does not include data for some of the smaller developing countries for which we have household data, we supplement the DAI data with estimates from other sources, particularly the FAO's domestic price and trade series.

To assess changes in protection at the country level, we consider changes in international, domestic and country-specific border prices of four key food items. Our estimates of the international price changes come from the World Bank's Global Economic Monitor (GEM) database. Because for most commodities the GEM reports a set of prices for specific varieties (e.g. US Hard Red Winter wheat etc.) we calculate and use unweighted averages of all available international prices.

For domestic prices, we turn to the available DAI and FAO databases which usually contain a single price estimate for most agricultural commodities and countries. For edible oils, where a producer price index was not available, we calculated a weighted price index including several important oil seeds (soybeans, sunflower, groundnuts, rapeseed) in addition to palm oil. In a very few cases where FAO producer price data were not available, we used the FAO 
GIEWS database to identify the changes in domestic prices using that source's most relevant price series available.

To get a sense of the extent of changes in trade restrictions during 2006-08, we present below some summary material for each of the four food items.

\section{Rice}

Rice prices increased substantially between 2006 and 2008. The first part of reports that the changes for three international indicator prices averaged close to 120 percent in nominal US dollars. National border price changes (shown in Appendix table 1 in US dollars) were generally smaller, with the median price increasing by 78 percent. Most of the border price changes that we observe range between 53 and 102 percent. The reasons they differ from the international reference price changes may include: contractual arrangements that delay adjustments in the prices of traded goods; differences between the types of rice traded; and freight costs that make the export prices that are quoted internationally more volatile than most border prices.

Changes in domestic prices of rice were more subdued than changes in the border prices. This is also shown in Appendix figure 1. The median price rise was only 44 percent, with half of the price increases in the 30 to 64 percent range. Because domestic prices generally rose less than international prices, we also observe a reduction in protection, ${ }^{12}$ with a median change of 18 percent. Most countries' protection rates fell between 0 and 30 percent.

\footnotetext{
${ }^{12}$ Protection is defined as the ratio of the domestic price to the border price of a like product. If there are no other price-distorting policies than border measures, as assumed here, this is both the farmers' nominal assistance coefficient and an indicator of the distortion to the domestic consumer price. For some countries this indicator may be negative, usually because it is an exporting country with an export restriction, although in rare cases it indicates import subsidization.
} 


\section{Wheat}

According to the World Bank's Global Economic Monitor database, the price of wheat traded internationally increased substantially between 2006 and 2008, with US soft red winter wheat rising by 71 percent and Canadian Western Red Spring wheat rising by 110 percent. Using the data from the FAO database, however, we observe much greater variation in border price changes between countries (Appendix table 1). Some countries experienced negligible price changes while other countries experienced price increases of over 200 percent. For the majority of countries, the wheat border price rise was between 80 and 120 percent.

Domestic wheat prices rose much less than the large increases in border prices for most countries. The median domestic price change was 70 percent, and most countries experienced a price increase between 35 and 100 percent (Appendix figure 1). Because domestic prices changed at very different rates from the border prices, there is a sharp reduction in protection. The observed median change in the protection index is only -0.1 percent, but most of the countries' protection fell between zero and 25 percent.

\section{Maize}

The international price of maize rose by 83 percent between 2006 and 2008 (Appendix table 1). The median change in border prices was 94 percent, with half the observations between 60 and 110 percent (Appendix figure 1). Domestic prices changed much less with a median price change of 49 percent and most countries experiencing increases in domestic prices between 30 and 85 percent. Corresponding to these differences in domestic and international price changes we observe a reduction in protection with a median fall of 17 percent and the majority of the cuts between 10 and 30 percent. 


\section{Edible oils}

Oilseeds and edible oils are much more complex to monitor than cereals because of the diverse set of commodities involved. To obtain at least a broad guide on price developments in this market, we examine three key oil products—palm oil, palm kernel oil, and soybean oil—to obtain the average changes in international prices shown in Appendix table 1 and the distribution of changes in border prices, domestic prices and protection in Appendix figure 1. In order to measure the changes in domestic and border prices for edible oils, we consider a consumptionweighted price index for palm oil and major oil seeds (soybeans, cottonseed, soybeans, and groundnuts). We report a distribution of so-defined border prices in and find that the median border price change was 85 percent and that the majority of border price changes were between 55 and 110 percent. As with other commodities, domestic prices changed much less with a median price change of 54 percent and most of price changes between 30 and 80 percent. The median fall in protection was 12 percent, with half of the falls between 2 and 30 percent. 
Appendix table 1: Changes in international indicator rice prices between 2006 and 2008

\begin{tabular}{|l|c|c|c|}
\hline & Price 2006, US\$/t & Price 2008, US\$/t & Change, percent \\
\hline Rice, Thai, A1.Special & 220 & 482 & 120.0 \\
\hline Rice, Thailand, 5\% broken & 305 & 650 & 113.0 \\
\hline Rice, Vietnamese, 5\% broken & 260 & 567 & 118.0 \\
\hline Rice average, unweighted & 262 & 566 & 117.0 \\
\hline Wheat, Canada WRS & 217 & 455 & 109.7 \\
\hline Wheat, US, HRW & 192 & 326 & 69.8 \\
\hline Wheat, US, SRW & 159 & 272 & 70.8 \\
\hline Wheat average, unweighted & 189 & 351 & 83.4 \\
\hline Maize & 122 & 223 & 83.1 \\
\hline Palm oil & 478 & 949 & 98.3 \\
\hline Palm kernel oil & 581 & 1130 & 94.4 \\
\hline Soybean oil & 599 & 1258 & 110.2 \\
\hline Oil average, unweighted & 553 & 1112 & 101.0 \\
\hline
\end{tabular}

Source: World Bank Global Economic Monitor database 
Appendix figure 1: Distribution of proportional changes in border and domestic prices, and protection 2006-2008

Rice
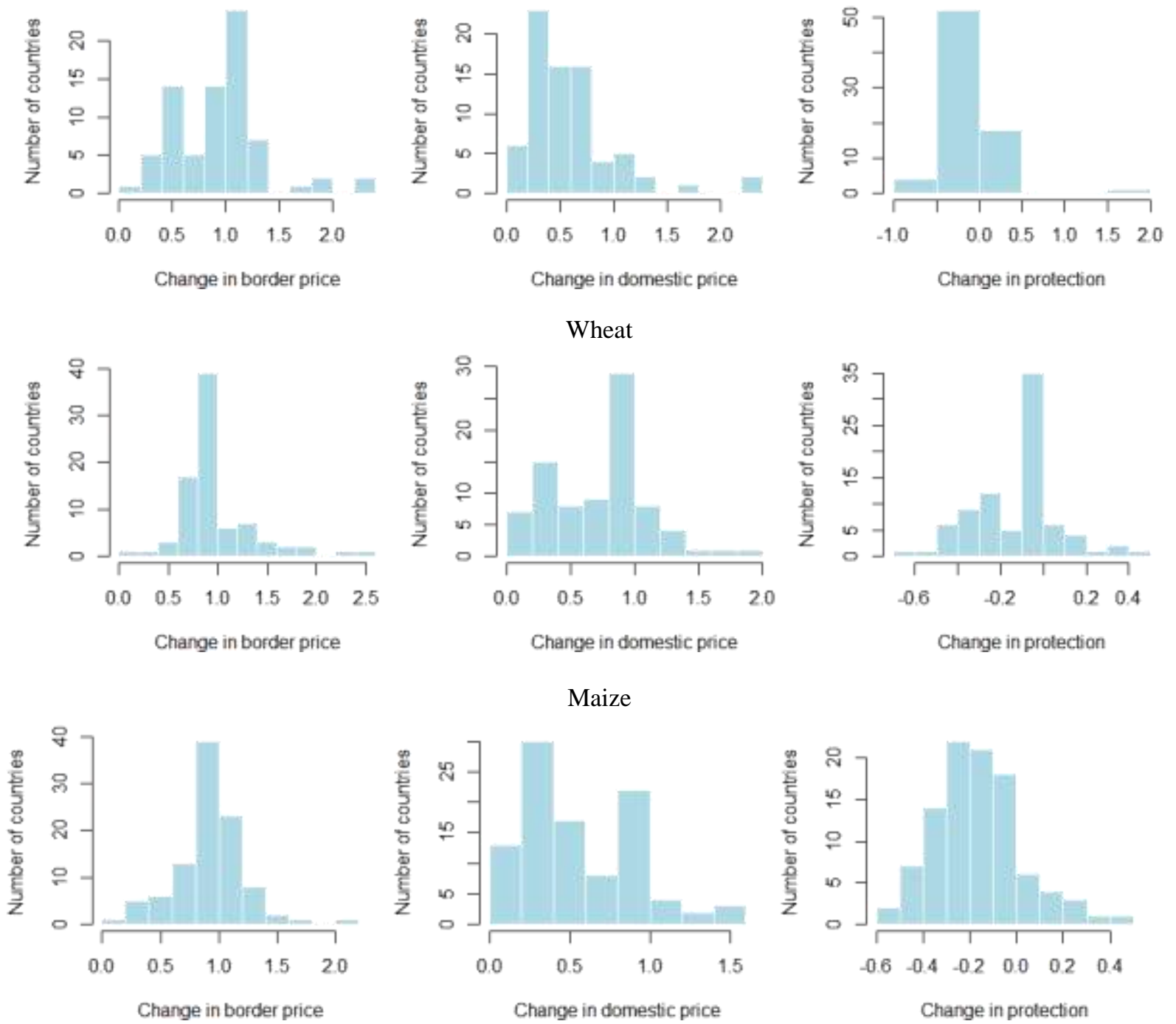

Maize
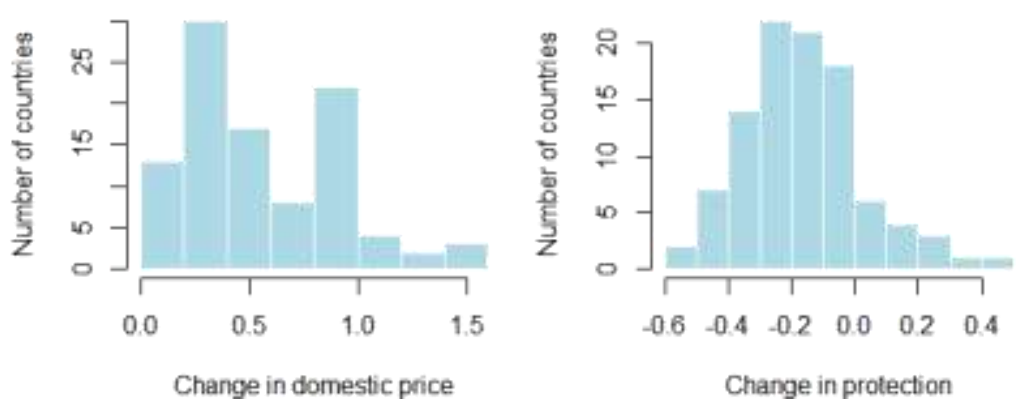

Edible oils
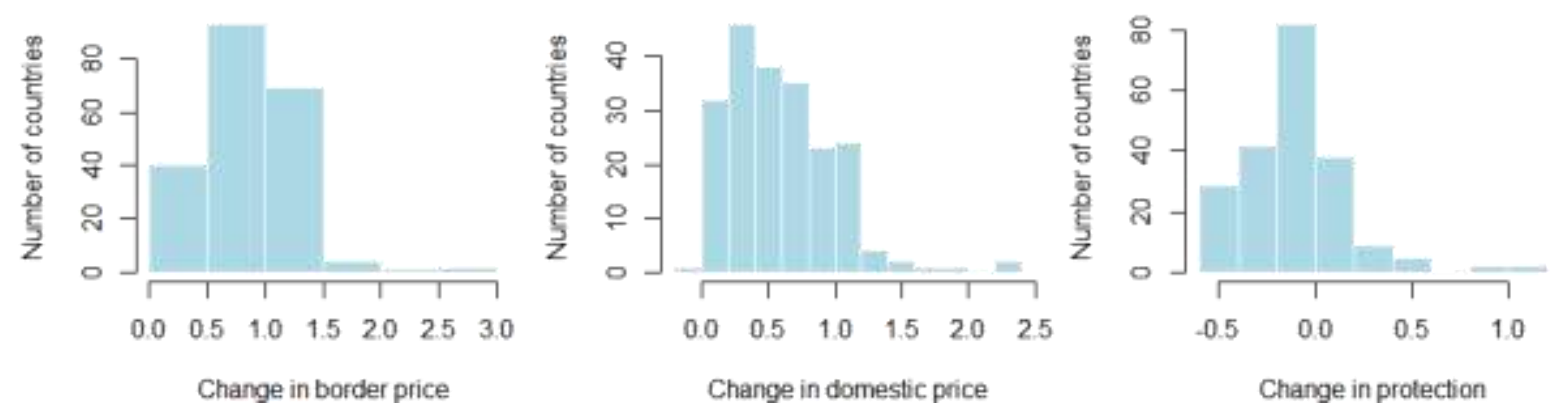

Source: Authors' calculations 